\title{
PEMAHAMAN REMAJA MASJID AL AMAN KERSEN BANTUL PADA PENGELOLAAN MEDIA SOSIAL SECARA SEHAT DAN CERDAS
}

\author{
Muhammad Sholeh*1, Untung Joko Basuki ${ }^{2}$ \\ Fakultas Teknologi Industri \\ ${ }^{1,2}$ Institut Sains \& Teknologi AKPRIND YogyakartaJl. Kalisahak 28 Yogyakarta \\ ${ }^{3}$ Fakultas Teknologi Informasi \\ muhash@akprind.ac.id*11 , untungjb@akprind.ac.id ${ }^{2}$
}

\begin{abstract}
Abstrak
Media internet saat ini sudah menjadi gaya hidup masyarakat Indonesia, di kalangan remaja penggunaan internet sudah menjadi kebutuhan yang pokok. Dominasi remaja dalam penggunaan internet lebih banyak penggunaan smart phone. Dalam penggunaan media internet ini, perlu diimbangi dengan informasi bagaimana menggunakan internet secara sehat dan cerdas.

Media internet, dapat digunakan untuk menambah wawasan tetapi juga bisa menjerumuskan para remaja ke hal-hal yang negatif. Agar para remaja, khususnya remaja masjid di Masjid Al Aman Kersen Bantul dapat menggunakan internet secara sehat dan cerdas, Takmir masjid mengadakan sosialisasi penggunaan internet sebagai media dakwah serta bijak dalam menggunakan internet dengan berinternet secara sehat dan cerdas dalam menangkal informasi yang bersifat hoax. Hasil kuesioner menunjukkan hampir 59\% responden berusia 15 tahun, $41 \%$ respon berusia variatif antara 16-20 tahun dan 89\% menggunakan internet melalui smart phone, 6\% menggunakan Wi-Fi atau modem dan hanya 5\% yang belum menggunakan internet.

Dari gambaran pengguna internet tersebut, para remaja perlu selalu diberikan pendidikan mengenai penggunaan internet yang sehat dan cerdas sehingga mereka tidak terjebak dalam halhal yang tidak diinginkan. Hasil dari pelaksanaan kegiatan ini, diharapkan muncul kesadaran bahwa dalam penggunaan internet khususnya media sosial dapat dilakukan dengan bijak, bijak dalam menuliskan postingan di media sosial, dapat memilah informasi yang positif dan informasi yang bersifat hoax.
\end{abstract}

Kata kunci : Remaja, Internet, Sehat, Cerdas

\section{PENDAHULUAN}

Era penggunaan internet saat ini sudah masuk semua batas usia dan daerah. Dengansemakin mudahnya penggunaan smart phonetentunya juga semakin mempermudah dalam melakukan aktifitas dengan menggunakan fasilitas internet. Hanya dengan smartphone, hampir semua kegiatan sudah dapat dilakukan, proses transfer uang tidak harus melalui teller atau ATM tetapi bisa menggunakan mobile banking. Demikian juga dalam proses pendidikan, anak didik dalam mencari materi pembelajaran tidak harus menggunakan buku tetapi dapat menggunakan internet untuk mencari bahan pembelajaran, Bahkan dengan berbasis teknologi informasi, materi pembelajaran lebih interaktif karena dilengkapi dengan multimedia.

Penggunaan internet bukan berarti tidak ada unsur yang dapat merugikan pengguna. Ibarat sebuah pisau, penggunaan pisau tergantung dari pengguna. Dari sisi positif,tentunya pisau tersebut banyak kegunaannya, tetapi apakah sebuah pisau tentunya dapat digunakan untuk hal-hal yang bersifat negatif, misal melukai orang lain. Demikian juga internet, sisi positif dan negatif tergantung dari pengguna. Di internet antara sisi positif dan negatif berbeda tipis.di Internet 
pengguna dapat mencari materi pembelajaran, mencari bahan diskusi tetapi juga bisa terjerumus dalam hal-hal negatif seperti pornografi, perjudian, kecanduan pada game dan lainnya. Sosialisasi menggunakan internet sehat dan cerdas dalam menangkal berita harus selalu disampaikan terutama pada kalangan remaja.

Hasil survey yang dilakukan oleh Asosiasi Penyelenggara Jasa Internet Indonesia (APJII)[1], pertumbuhan penggunaan internet sampai pada tahun 2017 sebanyak 143,36 juta dan pertumbuhan ini sangat signifikan jika dibandingkan dengan pengguna internet pada tahun 2016. Gambar 1, menunjukkan pertumbuhan pengguna internet pada tahun 2017.Dari 143,36 juta, pengguna paling banyak berusia antara 10-24 tahun sebanyak 66,2\%. Gambar 2, memperlihatkan komposisi pengguna internet berdasar usia.

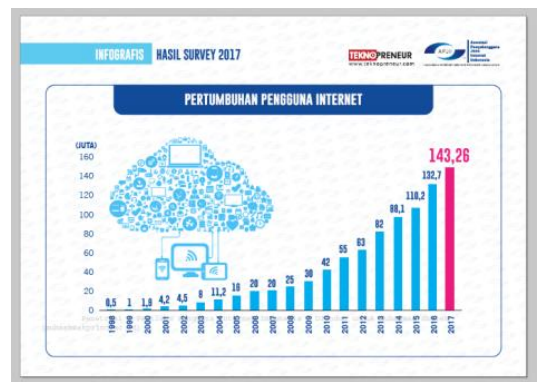

Gambar 1 pertumbuhan pengguna internet pada tahun 2017

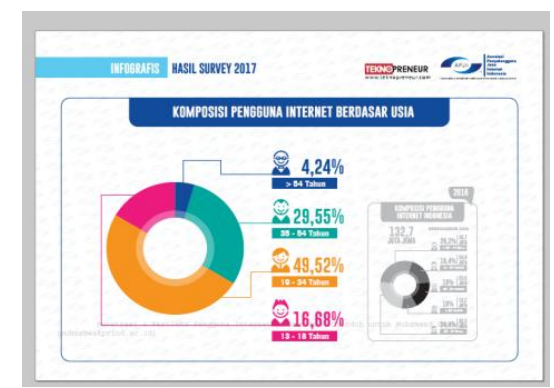

Gambar 2 Komposisi pengguna internet berdasar usia.

Hasil survey Masyarakat Telekomunukasi (mastel) tentang permasalahan hoax nasional yang dilakukan pada tahun 2017 [2]terutama dalam menyikapi berita-berita yang tidak benar. Hasil survei menunjukkan, proses pengecekan berita hoax adalah :

- Melalui Internet/ Search Engine 83\%

- Menanyakan keorang yang Dianggap Tahu $48.60 \%$

- Melalui Media Massa (Koran, TV, Radio) $44.30 \%$

- Melalui Media Sosial 36.80\%

Hasil survey mengenai tingkat kesulitan / memeriksa kebenaran berita heboh dari pengguna internet adalah

- Mudah 53.50\%

- Sulit $30.30 \%$

- Sangat Mudah $12.80 \%$

- Sangat Sulit $12.80 \%$

Berdasar hasil survey yang dilakukan oleh Mastelmenunjukkan bahwa pengguna internet sudah mulai sadar akan pentingnya melakukan internet sehat dan cerdas dalam memilah informasi yang tidak benar.

Hasil penelusuran studi literatur, didapat bahwa persoalan edukasi agar para remaja peduli menggunakan internet secara sehat dan cerdas harus selalu dilakukan. Beberapa hasil penelitian yang dilakukan diantaranya :

[3] dalam tulisan di jurnal JURNAL Untuk Mu negeRI mengupas tentang Perkembangan teknologi internet membawa perubahan yang sangat besar terhadap kehidupan manusia di segala bidang. Pemanfaatan internet sehat tentunya bisa membuat kehidupan lebih berkemajuan, hal ini disebabkan banyaknya informasi dan pengetahuan bisa diambil oleh pengguna dari situs-situs yang ada di internet. Tantangan tersendiri terkait perkembangan internet adalah pada generasi muda terutama yang berada di tingkat SMA. Sehingga diperlukan cara untuk mengedukasi mereka agar dapat menggunakan fasilitas yang ada di internet untuk tujuan yang positif. Guru sebagai pendidik tentunya dapat menjadi fasilitator untuk mengarahkan peserta didiknya dalam penggunaan internet sehat. Tujuan dari pengabdian kepada masyarakat ini adalah untuk memberikan edukasi kepada para guru di lingkungan SMA Negeri 9 Pekanbaru dalam hal 
pemanfaatan internet menuju kehidupan yang berkemajuan. Dengan adanya edukasi ini diharapkan dapat menjadi tongkat estafet dalam membantu mengarahkan para siswa berkaitan dengan penggunaan internet yang positif.

[4],berdasarkan hasil studi literatur dan penelitian yang dilakukan, penggunaan internet pada siswa SMA, didapat beberapa hal yang menarik seperti mayoritas para pelajar diperkenalkan oleh temannya dalam menggunakan internet. Selain itu, akses internet mereka lebih banyak kepada kegiatan senang-senang saja walaupun diakses dari rumah dan menggunakan smartphone sehingga penulis mendapatkan beberapa kesimpulan :para pelajar sudah mengetahui apa saja dampak negatif dari penggunaan internet terbukti dengan mayoritas sudah menyadari dampak negatif, para pelajar masih menganggap bahwa ketagihan internet dapat menurunkan prestasi para pelajar. Hal ini dikarenakan kurangnya pemakaian internet untuk kegiatan yang berkaitan dengan akademik dan para pelajar tidak mendapatkan edukasi yang baik tentang internet dan cara penggunaannya, kurang kepedulian dan pendidikan dari keluarga dan tenaga pendidik dalam mengembangkan akses internet sehingga pengawasan dan pemanfaatan dari Internet dirasa cukup kurang dan terkesan membiarkan para pelajar untuk bebas mengekspresikan dan menjelajah isi dunia melalui internet tanpa mengetahui pentingnya internet serta dampak positif yang bisa didapatkan dari layanan tersebut

[5] dalam tulisannya mengupas berbagai upaya untuk membendung informasi negatif terus diupayakan oleh berbagai elemen masyarakat, tetapi tidak efektif jika perilaku penggunaannya tidak diubah. Remaja merupakan kalangan yang paling rentan dalam penyalahgunaan kemajuan teknologi internet, maka perlu upaya serius untuk memberikan pengetahuan dan keterampilan yang benar dalam memanfaatkan kemajuan tersebut. Pelatihan desain web dalam rangka pengembangan keterampilan menulis ilmiah, meskipun dalam skala kecil, merupakan salah satu upaya untuk meningkatkan keterampilan siswa dalam menyediakan konten positif di internet.

\section{METODE}

\section{Khalayak Sasaran Khalayak}

Sasaran pengabdian masyarakat ini adalah para remaja masjid yang tergabung dalam remaja masjid Al Aman di dusun Kersen Kabupaten Bantul. Jumlah peserta yang mengikuti sosialisasi sebanyak 27 dan rentang usia antara 13-20 tahun

\section{Metode Kegiatan}

Sebelum dilakukan sosialisasi terlebih dahulu para remaja mengisi kuesioner.

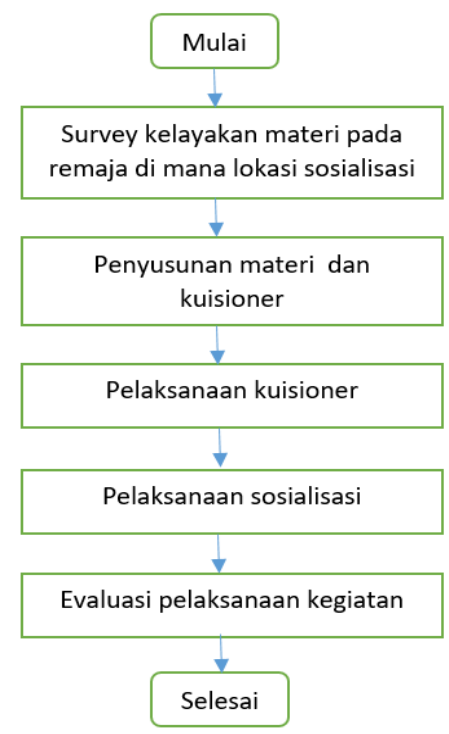

Gambar 3. Alur proses pelaksanaan pengabdian 
Adapun deskripsi dari masing-masing proses adalah sebagai berikut:

a. Survey kelayakan materi pada remaja di mana lokasi sosialisasi

Langkah awal ini dilakukan dengan melakukan penjajagan materi yang sesuai dengan kebutuhan remaja masjid.

b. Penyusunan materi dan kuesioner

Materi yang dimaksud di sini berupa materi sosialisasi dan kuesioner yang nantinya sebagai instrumen dalam melakukan evaluasi kegiatan dan mengetahui sejauh mana penggunaan media internet dalam penggunaan nya

Bahan penyusunan materi disadur dari https://internetsehat.id/dan buku internet sehat

c. Pelaksanaan kuesioner

Kuesioner diberikan pada remaja dengan tujuan mengetahui sejauh mana para remaja dalam menggunakan internet

d. Pelaksanaan sosialisasi

Penyampaian materi disampaikan dalam bentuk penjelasan dan contoh-contoh aktual terutama kejahatan internet, membedakan informasi hoax atau asli serta dampak hukum dalam proses me posting yang bersifat negatif.

e. Evaluasi pelaksanaan kegiatan

Evaluasi dilakukan dengan memetakan hasil sosialisasi dan hasil kuesioner

\section{HASIL DAN PEMBAHASAN}

\section{Hasil Kuesioner}

Dalam olah data ini, banyak peserta sosialisasi internet sehat dan cerdas sebanyak 27. Mayoritas berusia 15 tahun (59\%) dan masih di bangku SMP. 41\% berusia antara 13,15-20 tahun. Gambar 4, usia peserta yang mengikuti sosialisasi

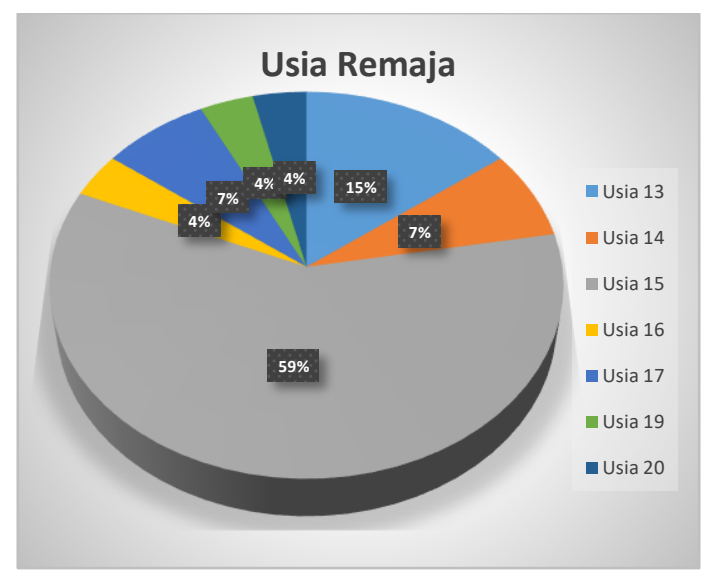

Gambar 4 Usia Pengguna Internet

Usia remaja merupakan usia yang keinginan tahu dalam sesuatu hal sangat besar, demikian juga dalam penggunaan internet sudah semestinya para remaja diarahkan agar dapat menggunakan internet secara sehat dan bijak serta cerdas dalam memilah informasi.

Hasil analisis dilakukan terhadap beberapa aspek yang dilakukan para remaja terkait media sosial dan pengaruhnya terhadap interaksi sosial pada kehidupan sehari-hari. Beberapa hasil dari kuesioner diantaranya:

1. Internet merupakan media belajar yang efektif untuk memperoleh informasi seputar materi pelajaran di Sekolah ?

Hasil pertanyaan ini menunjukkan, bahwa penggunaan internet dapat mendukung dalam proses belajar mengajar. Dengan internet, materi pembelajaran yang diberikan oleh guru dapat dicari di internet, sehingga media internet dapat membantu dalam pelaksanaan pembelajaran. 
2. Dalam keseharian anda, apa yang anda lakukan dengan menggunakan jaringan INTERNET?

Dari pertanyaan penggunaan internet, para remaja lebih banyak memilih untuk mencari hiburan seperti game dam lainnya serta juga digunakan untuk mendukung tugas sekolah. Hal ini menunjukan usia remaja yang tentunya ingin lebih banyak bermain dan dalam penggunaan internet para remaja juga menggunakan untuk mendukung tugas sekolah.

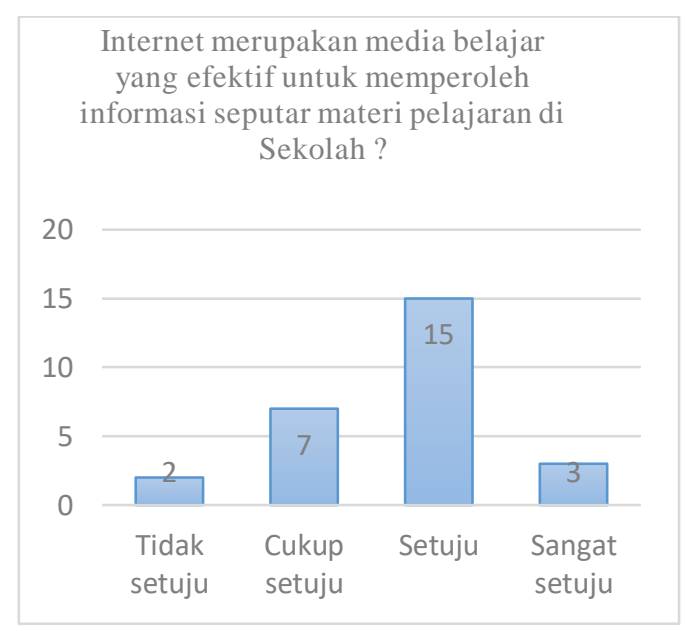

Gambar 5, Penggunaan internet untuk mendukung proses belajar mengajar

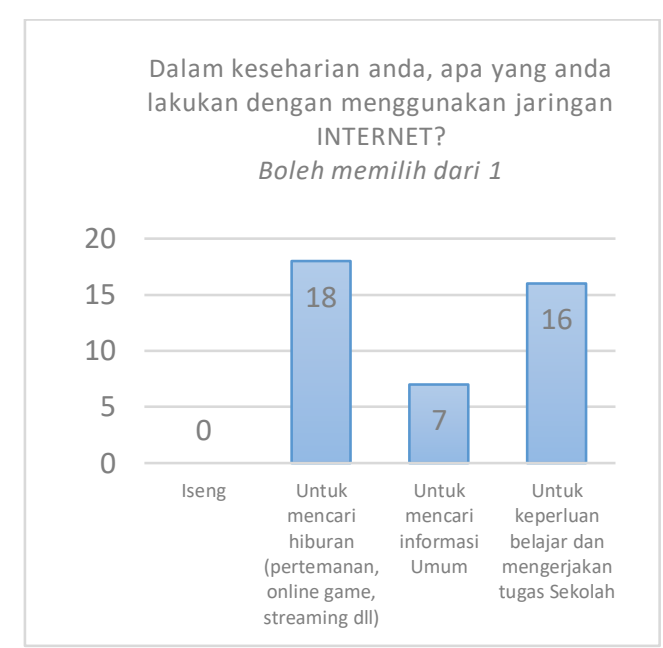

Gambar 6, Penggunaan internet sehari-hari

3. Update status

Gambar 7, merupakan hasil kuisioner dengan pertanyaan frekuensi dalam mengupdate status.Dari hasil kuesionerdi atas, mayoritas remaja, dalam mengupdate status masih tidak tentu dan ini menunjukkan penggunaan media sosial belum menjadi sesuatu yang sangat penting.

4. Informasi pada halaman Profil

Gambar 8, memperlihatkan data-data pribadi yang di informasikan dalam media sosial. Hasil kuisioner, para remaja masih perlu adanya pemahaman bahwa tidak semua biodata diinformasikan dalam halaman profil media sosial. Ada beberapa biodata yang bersifat privasi yang semestinya tidak ditulis dalam media sosial.

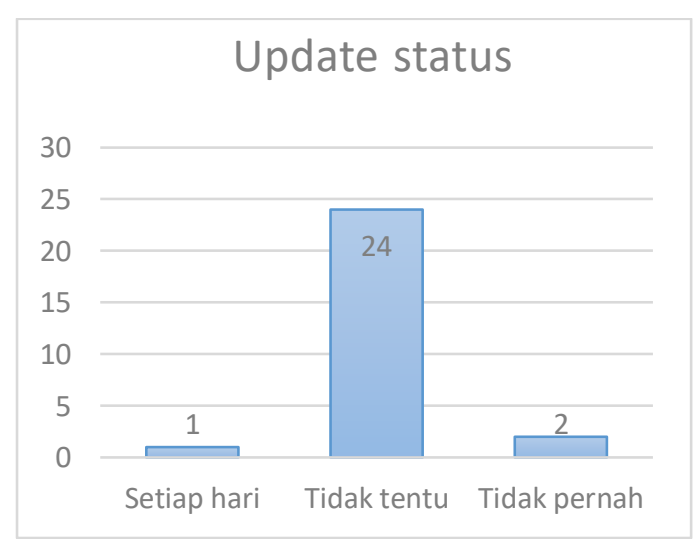

Gambar 7 Frekuensi update status

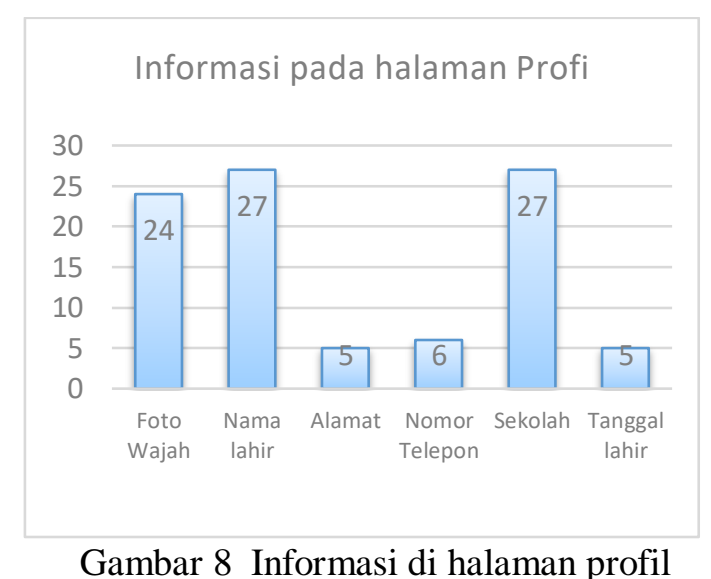

Gambar 8 Informasi di halaman profil

\section{Apa yang dimaksud HOAX}

Pada gambar 9, menujukan bahwa, pemahaman terhadap informasi yang provokatif atau hoax, mereka sudah memahami dan sudah dapat membedakan antara informasi yang nyata dan hoax.

6. Alasan Meneruskan Berita heboh 
Salah satu kebiasaan dalam bersosial media adalah meneruskan berita/ tulisan yang diterima. Dalam pertanyaan ini, alasan yang disampaikan dalam meneruskan berita adalah berita yang diterima merupakan kiriman berita dari orang yang dapat dipercaya, mengira bermanfaat dan mengira benar. Artinya para remaja harus mendapatkan pendidikan bagaimana dapat memilah berita yang heboh tersebut benar atau hoax. Walaupun berita yang diterima tersebut dari orang yang dipercaya, proses seleksi dan filtering harus tetap dilakukan terutama untuk mengecek kebenaran berita.

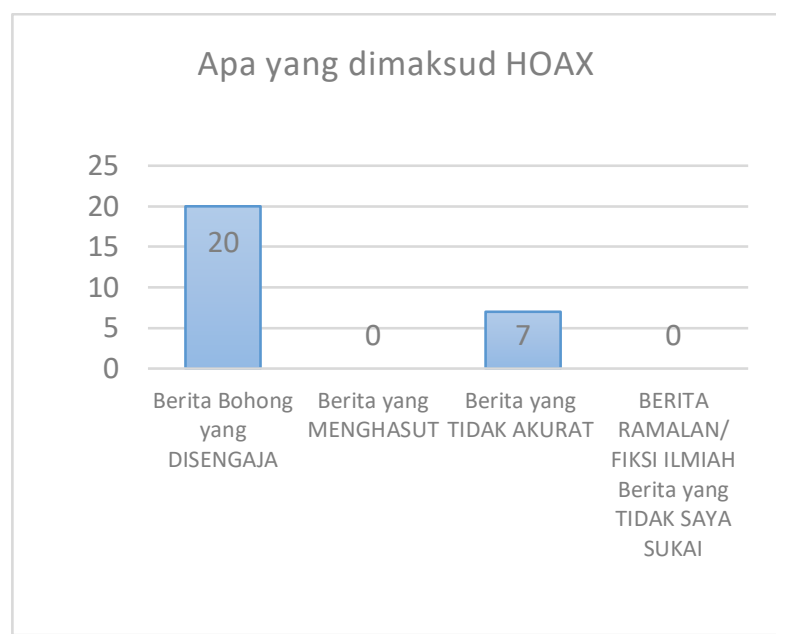

Gambar 9 Pemahaman mengenai Hoax

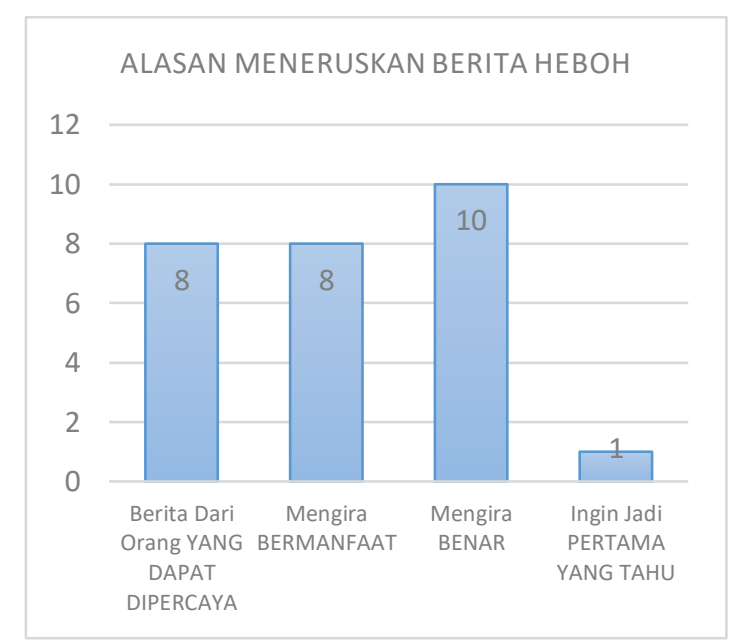

Gambar 10 Alasan meneruskan berita Hoax

7. Bentuk Hoax yang Paling Sering diterima

Sebagai pengguna media sosial, kiriman postingan tidak dapat dihindarkan dan postingan yang sering diterima adalah tulisan dan gambar 11 menampilkan bentuk informasi yang dikatergaorikan hoax.

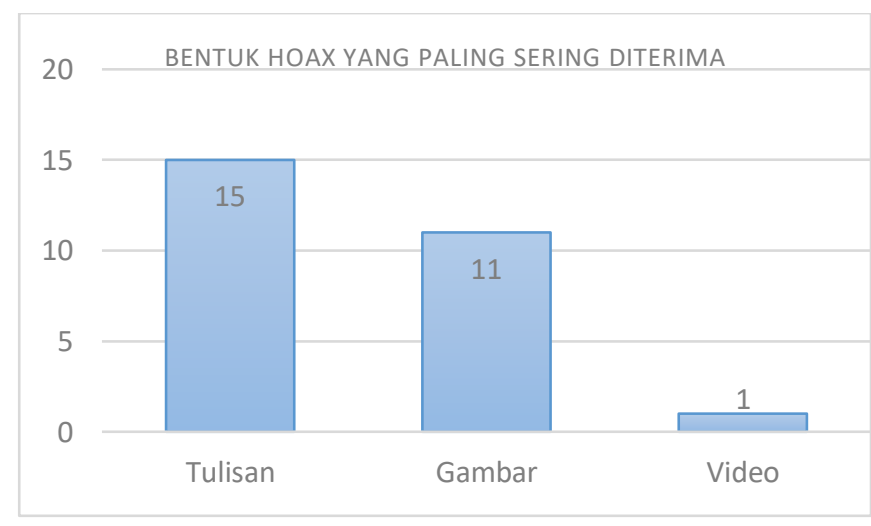

Gambar 11 Bentuk Hoax yang Paling Sering diterima

\section{Materi sosialisasi Internet Sehat}

Kegiatan pengabdian masyarakat yang diberikan pada remaja masjid ini dilakukan dengan memberikan sosialisasi dan ceramah bagaimana remaja dapat menggunakan smartphone atau media internet dengan baik dan benar.

Disamping dapat menggunakan internet dengan baik dan benar, siswa juga diberikan motivasi bagaimana dapat menggunakan internet sebagai media untuk pembelajaran. Internet tidak hanya digunakan untuk sarana komunikasi, pencarian data tetapi juga digunakan untuk pencarian bahan pembelajaran. Dalam sosialisasi ini ditekankan bagaimana para remaja masjid dapat menggunakan internet dengan bijak, sehat dan aman. 
Dalam sosialisasi ditekankan bahwa tidak seluruh isi di Internet dapat bermanfaat. Karena sifatnya yang cenderung bebas tanpa kontrol pihak manapun, maka ada saja materi atau isi yang bersifat negatif di Internet ataupun yang dikirim/ terkirim melalui Internet. Misal pornografi, perjudian, sadisme dan rasialisme. Belum lagi dengan aneka macam program jahat (virus, worm, trojanhorse, spyware, adware) yang dapat mencuri bahkan merusak data di komputer, serangan email sampah (spam), penipuan, pelanggaran privasi hingga pelecehan seksual. Tetapi dengan pemahaman yang cukup tentang Internet serta didukung kedewasaan dalam memilih maupun memilah hal yang baik dan buruk, maka akan memaksimalkan dampak positif Internet serta sekaligus meminimalkan dampak negatifnya.[6]

\section{Cerdas menangkal Hoax}

Permasalahan lain yang sering muncul dalam penggunaan internet khususnya media sosial adalah adanya informasi yang isi beritanya belum tentu benar. Sebagai pengguna media sosial, kehati-hatian dalam menerima dan meneruskan postingan yang tidak jelas harus benar-benar diperhatikan. Informasi yang tidak jelas dan bersifat provokatif sering disebut dengan hoax.

Langkah-langkah meminimalkan berita yang masuk hoax diantaranya :

1. Perhatikan Sumber Berita

2. Jangan terlalu percaya pada foto dan

3. Baca keseluruhan isi Berita

4. Cari dan Bandingkan dengan situs lain

5. Sebaiknya bersikap netral terhadap sebuah berita

6. Hati-hati membagikan postingan yang didapat

7. Kritis dan Cek

Dari materi yang disampaikan, peserta diharapkan lebih berhati-hati dalam menggunakan media sosial, tidak dengan mudah meneruskan postingan yang didapat, tidak menuliskan postingan yang menjelekkan pihak lain serta menggunakan internet' secara sehat dan cerdas. Gambar 12 16peserta dari para remaja dan tim yang mengikuti sosialisasi internet sehat.

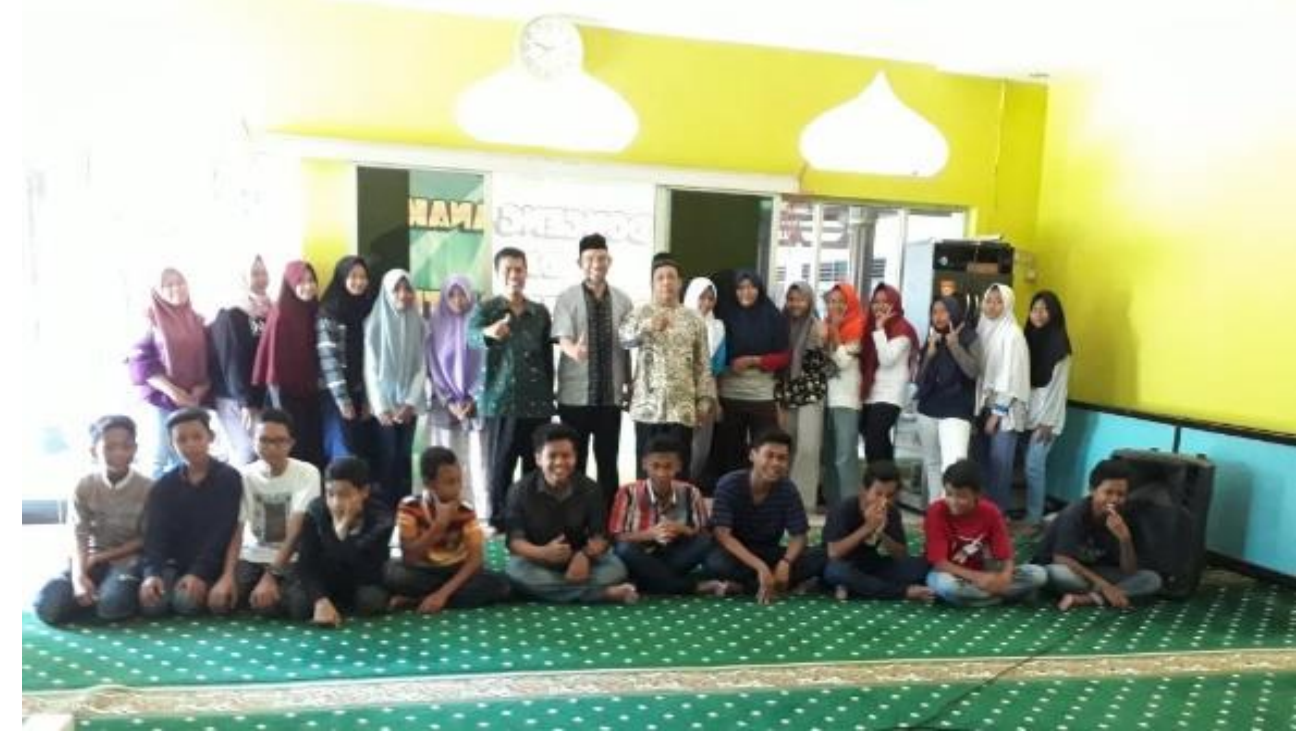

Gambar 12 Peserta dan nara sumber dalam sosialisasi internet sehat

\section{KESIMPULAN}


Agar penggunaan internet memberikan nilai positif, pengguna internet harus cerdas dalam memilah informasi dan cerdas dalam menggunakan internet. Remaja sebagai pengguna yang dominan dalam menggunakan internet, haus selalu diberikan pendidikan dalam berinternet. Sebagai upaya untuk memberikan pendidikan internet sehat, remaja masjid Al Aman Kersen Bantul, memberikan sosialisasi bagaimana menggunakan internet secara sehat dan cerdas. Hasil dari sosialisasi ini dharapkan para remaja mulai berhati-hati dalam menruskan postingan yang didapat, tidak mudah menuliskan kata-kata yang bersifat provokatif atau menjelekkan orang lain serta membatasi data-data pribadi yang di posting di media sosial.

\section{DAFTAR PUSTAKA}

[1] anonim, "PENETRASI \& PERILAKU PENGGUNA INTERNETINDONESIA 2017," APJII, Jakarta, 2017.

[2] Anonim, "HASIL SURVEY MASTEL TENTANG," Masyarakat Telematika Indonesia, Jakarta, 2017.

[3] D. Winarso, A. Syahril, E. Arribe and R. Diansyah, "PEMANFAATAN INTERNET SEHAT MENUJU KEHIDUPAN BERKEMAJUAN," JURNAL Untuk Mu negeRI, vol. 1, no. 1, pp. 19-23, 2017.

[4] S. Ikhsani and N. A. R. , "HUBUNGAN ANTARA TINGKAT PENGGUNAAN INTERNET DENGAN PERSEPSI PENINGKATAN PRESTASI PADA PELAJAR SMA DI SURABAYA," Jurnal Teknologi dan Sistem Informasi STMIK Royal, pp. 86-91, 2016.

[5] W. Parimita, H. Eryanto and R. Faslah, "PENGEMBANGAN PERILAKU BERINTERNET SEHAT MELALUI PEMBUATAN BLOG ILMIAH SISWA," Jurnal Pemberdayaan Masyarakat Madani (JPMM, vol. 1, no. 1, pp. 33-45, 2017.

[6] D. B.U., Internet Sehat, Jakarta: internetsehat.org, 2016. 